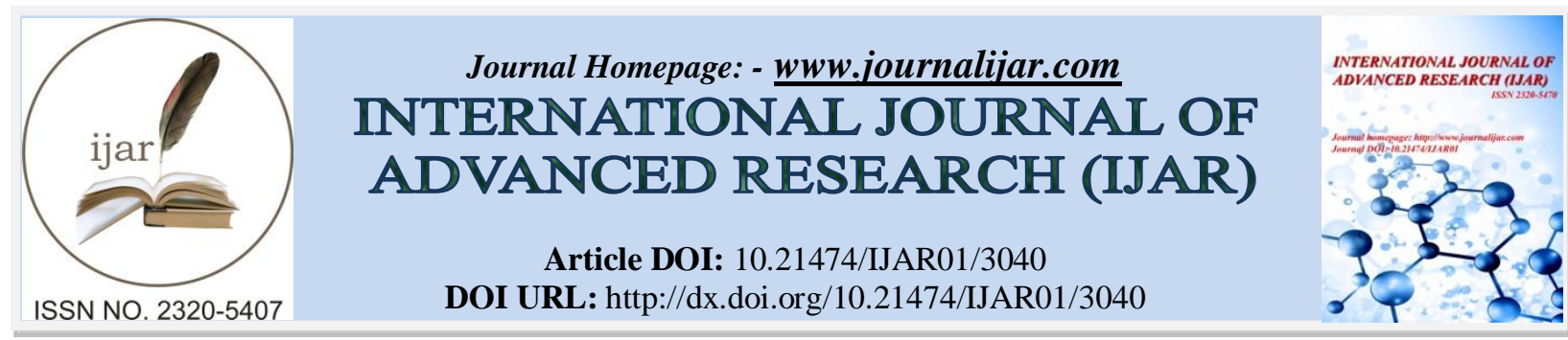

RESEARCH ARTICLE

\title{
WORK PARTICIPATION OF TRIBAL WOMEN IN GAJAPATI DISTRICT: A STATESTICAL ANALYSIS OF ODISHA.
}

Mr. Junas Sabar.

Ph.D Scholr, Women's Studies, WSRC, Berhampur University,Ganjam, Odisha, Pin-760007.

\section{Manuscript Info}

Manuscript History

Received: 30 November 2016

Final Accepted: 28 December 2016

Published: January 2017

Key words:-

Tribal, Gender, Work Participation, Agriculture, Livelihood.

\section{Abstract}

This paper has been written on the basis of qualitative and quantitative data collected from secondary source and discussed work participation of tribal women in Gajapati district in a descriptive manner. The tribal women have been equal partners with tribal men in the contribution to household economy. Women do more physical labour in their agricultural fields and forest than that of the tribal men. Tribal women have usually enjoyed a higher social status in their own communities. The literacy rate among the tribal's and more so in case of tribal women is quite low and this is also associated with poor nutritional and health status among the tribal's. They are engaged in various traditional occupations like mixed farming, hunting, Jhoom cultivation and shifting cultivation to settled agriculture. A very negligible percent are engaged in non-agricultural activities The Scheduled Tribes constitute $8.2 \%$ of India's total population. $9.2 \%$ of the country's scheduled tribe population is found in Odisha, which is third highest in the country and the scheduled tribes account for $50.78 \%$ population of the district.

Copy Right, IJAR, 2016,. All rights reserved.

\section{Introduction:-}

Agriculture is the most primitive occupation of the tribal people. The people had changed their cultivation pattern from traveller's cultivation to settled cultivation, but some of the practices have remained unchanged among many groups of farmers. They are engaged in various traditional occupations like mixed farming, hunting, Jhoom cultivation and shifting cultivation to settled agriculture. The tribal people are practices traditional agricultural wisdom for their livelihood.

Tribal people have traditionally lived in about $15 \%$ of the country's geographical areas, mainly forests, hills and undulating inaccessible terrain in plateau areas, rich in natural resources. They have lived as isolated entities for centuries, largely untouched by the society around them. This seclusion has been responsible for the slower growth, dissimilar pattern of their socio-economic and cultural development and inability to negotiate and cope with the consequences of their involuntary integration into mainstream society and economy. Tribals continue to be socioeconomically backward. One of the most distinguishing features of the rural economy of Gajapati has been the growth in the number of agricultural workers, cultivators and agricultural labourers engaged in crop production. Agricultural labourers, especially in smaller villages away from towns and cities, are generally unskilled workers carrying on agricultural operation in the centuries old traditional wages. Agriculture is the back bone of many developing countries. Women account for more than half of the work force by participating in different activities, either directly or indirectly. The gender division of labour varies from one society and culture to another, and within 
each culture external circumstances influence the level of activity (Nigist, 2004). Women are the unavoidable part of any development programmes whether it is for developed or developing country (Raksha etal, 2016). Odisha is one of the poorest states in India, with an estimated $47 \%$ of its population living on less than a dollar a day (Haans \& Dubey, 2003). A regional and social group-wise analysis of poverty in Odisha highlights the fact that the population in Scheduled Areas is comparatively much poorer than the population in non-Scheduled Areas, and that Scheduled Tribes are the poorest groups (Kumar, K., 2005). Women have played and continue to play a key role in the conservation of basic life support systems such as land, water, flora and fauna (Prasad C. etal, 1992). Women play a central role in the agriculture economy (Chauhan, J., etal, 2016).

Women's work participation is considered as an important indicator of women's participation in economic activities of the State. Women's contribution though not recognized in all spheres of activity is significant. Despite their overall input to the economy they have limited access and control over the resources and productive assets. Wage gaps and discrimination against women in labour markets lower their participation. Women's work participation among the Scheduled Tribe in India fell marginally from $44.8 \%$ in 2001 to $43.5 \%$ in 2011. In Odisha Women's work participation rate increased from $42.2 \%$ in 2001 to $43.9 \%$ in 2011. In Gajapati district women's work participation rate decreased from $49.7 \%$ in 2001 to $46.8 \%$ in 2011 . The economy of Schedule Tribe areas is primarily subsistence oriented and based upon a combination of agriculture, forestry and wage labour (Odisha review, 2014).

As per 2011 census, Out of sixty-two (62) scheduled tribe population of India is 84,326,240 constituting 8.2\%, Odisha scheduled tribes (ST) population as 8,145,081 constituting $22.1 \%$ and Gajapati district scheduled population as 263,476 constituting $50.78 \%$. district wise distribution of the individual scheduled tribe shows that khond have the highest proportion i.e. 93.3 percent in kandhamala district, followed by Nayagarh as 76.9 percent, Baudh 76.4 percent and Rayagada i.e. 71.1 percent of the district. Gond has the highest concentration in Nabarangapur districts followed by Nuapada district whereas Santal and Kolha are primarily concentrated in Mayurbhanj district. Other four scheduled tribes i.e. Munda, Saora, Shabar and Bhottada are primarily concentrated in Sundargarh, Bargarh, Gajapati and Nabarangapur district. The scheduled tribes account for 50.78 percent population of Gajapati district and khond as 14.86\%, Saora 32.21\% and Shabar 50.84\% are the largest tribal groups in the district (Census 2011, Orissa review).

In Odisha all Scheduled Tribe workers (in percentage)

\begin{tabular}{|l|l|l|l|l|l|l|l|l|l|}
\hline $\begin{array}{l}\text { Economic } \\
\text { category }\end{array}$ & $\begin{array}{l}\text { All } \\
\text { Scheduled } \\
\text { Tribes }\end{array}$ & Khond & Gond & Santal & Kolha & Munda & Saora & Shabar & Bhottada \\
\hline Cultivators & $\mathbf{3 3 . 3}$ & 39.1 & 39.1 & 32.3 & 25.8 & 23.4 & $\mathbf{2 9 . 6}$ & 27.5 & 32.6 \\
\hline $\begin{array}{l}\text { Agricultural } \\
\text { Labourers }\end{array}$ & $\mathbf{4 6 . 9}$ & 46.8 & 46.6 & 45.1 & 47.6 & 41.7 & $\mathbf{5 4 . 3}$ & 55.3 & 58.2 \\
\hline $\begin{array}{l}\text { Household } \\
\text { Industry } \\
\text { Workers }\end{array}$ & $\mathbf{4 . 8}$ & 3.6 & 3.3 & 9.3 & 7.9 & 5.3 & $\mathbf{2 . 8}$ & 1.4 & 0.7 \\
\hline $\begin{array}{l}\text { Other } \\
\text { Workers }\end{array}$ & $\mathbf{1 5}$ & 10.5 & 11 & 13.3 & 18.8 & 29.5 & $\mathbf{1 3 . 3}$ & 15.8 & 8.6 \\
\hline
\end{tabular}

*Source: Data highlights- the scheduled tribes, Orissa, Census of India 2001. 


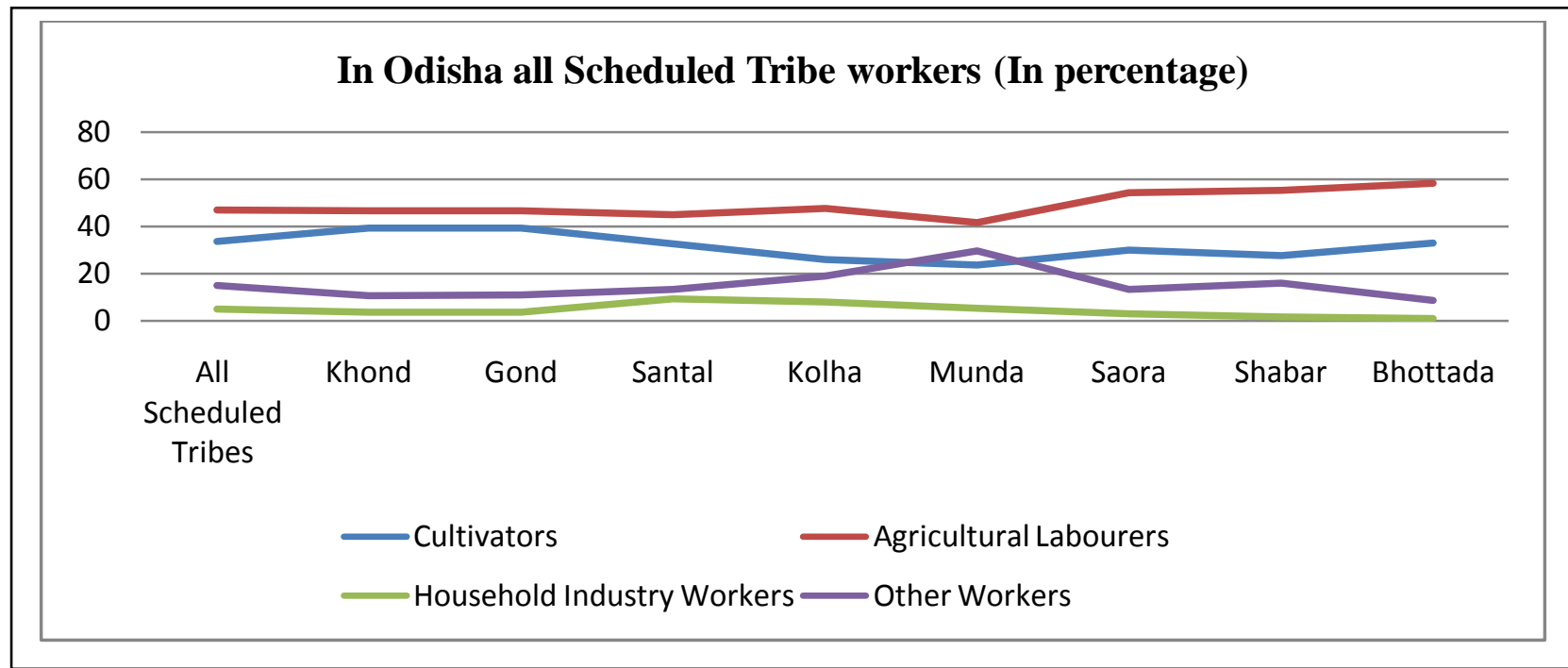

The Work Participation Rate of the Scheduled Tribes population is 49 per cent, which is equal to that of all Scheduled Tribes at the national level (49.1 per cent). There has been a slight decline of 0.4 per cent in the Work Participation Rate of the tribes during 1991-2001. While there has been a decline in male Work Participation Rate from 58.9 to 54.8 per cent, female Work Participation Rate (43.2 per cent) has increased by 3.4 per cent during 1991-2001. Among the total workers, 57.4 per cent are main workers and this proportion is much below the national average recorded for all Scheduled Tribes (68.9 per cent).

Among the major tribal groups i.e. Khond, Gond, Shabar, Saora and Bhattada have higher work participation rate than that of the State as well as national average for recoded for all scheduled tribes. Agricultural labourers constitute the highest proportion 46.9 percent among the total workers. Cultivators $33.3 \%$, other workers $15 \%$ and Household Industry constitute between as $4.8 \%$. These Soura populations contribute to the four Economic Categories i.e. Cultivators 29.6 percentage, Agricultural Labourer 54.3 percentage, Household Industry Workers 2.8 percentage only and Other Workers 13.3 percentage (see figure-1).

Worker and Non-Worker in Gajapati 2001-2011

\begin{tabular}{|l|l|l|l|l|}
\hline & \multicolumn{2}{|l|}{ Worker and Non-Worker in Gajapati 2001 } & \multicolumn{2}{l|}{ Worker and Non-Worker in Gajapati 2011} \\
\hline & Worker & Non-Worker & Worker & Non-Worker \\
\hline Male & 56.6 & 43.4 & 55.1 & 44.9 \\
\hline Female & 49.7 & 50.6 & 46.8 & 53.2 \\
\hline
\end{tabular}

(Source: Census of India 2011 final data, Registrar General of India), Databook for PC: $4^{\mathrm{TH}}$ Aug-2014. Census of India 2011, Primary Census Abstract Figure at a Glance and Data Highlight.

Worker and Non-Worker in Gajapati 2001-2011

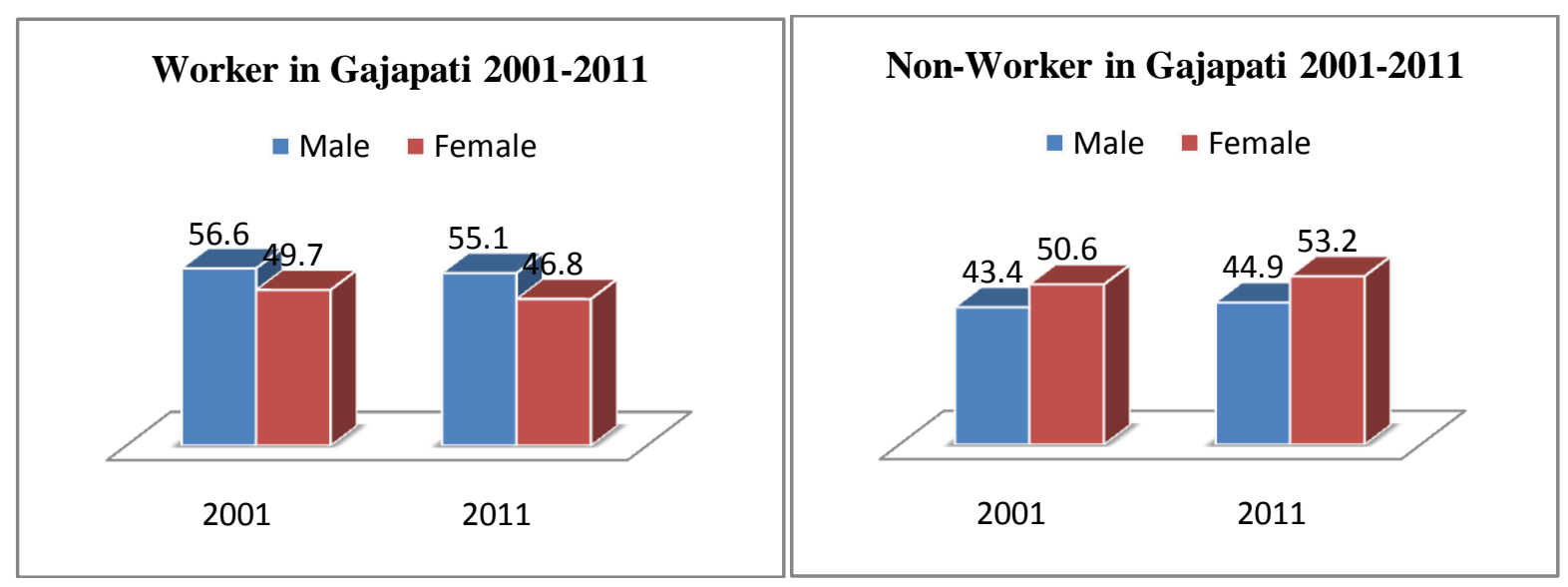


In Gajapati district we find Women constitute $50 \%$ of the workforce where as men constitute $57 \%$ of the total workers. Among non-worker women are more (50.6) in comparison to men (43.4). This is trending all India, all Odisha level also. But same how 50\% Women Work Participation Rate shows a significant highest of Women Work Participation Rate (WWPR) in Gajapati district. May be due to high concentration \% of tribal population are engaged as marginal worker for their own survival. This is a marginal status of tribal women in Gajapati district. Which will be further clarified while stratify women engaged in Agrarian sector (see figure-2).

Agricultural related activities are picking and threshing of paddy crops followed by harvesting, winnowing, storage, making threshing yard, bagging/packing and marketing of agricultural produce. The roles of tribal farmwomen in all these operations were observed up to the highest importance level (Chayal and Dhaka, 2010). Agriculture production is dependent on rainfall (Hans Asha, 2014)

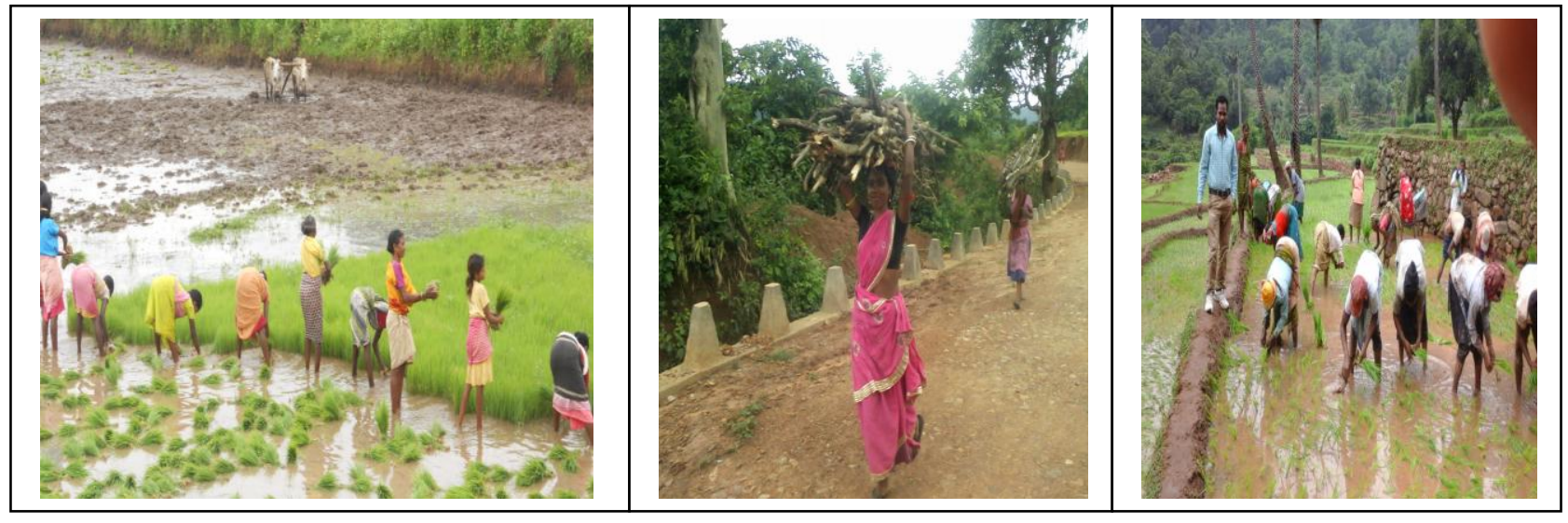

Agricultural pattern in our study area is primarily based on hill cropping pattern. Mostly people go for the cultivation of Ragi, Corn, Janna as main crop in year. And for secondary crop almost all families go for Jhudunga, Kandula and Kulata. Mostly people go for kharif cultivation and very few people go for rabbi cultivation where these are mostly found in wet land area (joba khiari). There is no irrigation facility in our study area of Gajapati district, though the river Mahendra Tanaya is flowing in this district. The perusal of the data in regards to participation of tribal farm women in sowing operation revealed that the highest participation of tribal farmwomen was observed in sowing, transplanting followed by stubble collection, clod crushing and seedbed preparation (Chauhan, N. M. \& Thakor, R, 2006).

Our study area among men 77 per cent are agricultural farmers and 23 per cent are wage labourers. From among our women respondents 97 per cent are daily worker and 3\% are housewives. But these daily wage workers among women also constitute agricultural workers.

Our study area are reflects that very few families are doing multi crop cultivation i.e. around $13 \%$. Nearly $87 \%$ are depending on their single crop cultivation which is a very poor source of earning. Cash cropping in our study area are such as Mango, Banana, Cashew, Lemon, Orange, Jackfruit and Pineapple cash crop. The cash crops in the area are mainly citrus fruits, Cashew, Mango and Orange etc.

One of the most distinguishing features of the rural economy of India has been the growth in the number of agricultural workers, cultivators and agricultural labourers engaged in crop production. The phenomena of underemployment, under-development and surplus population are simultaneously manifested in the daily lives and living of the agricultural labourers. They usually get low wages, conditions of work put an excessive which they get is extremely irregular.

Agricultural workers constitute the most neglected class in Indian rural structure. Their income is low and employment irregular. Since, they possess no skill or training, they have no alternative employment opportunities either. Socially, a large number of agricultural workers belong to scheduled castes and scheduled tribes. Therefore, they are a suppressed class. They are not organized and they cannot fight for their rights. Because of all these reasons their economic lot has failed to improve even after four decades of planning. 


\section{Summary:-}

This paper focuses attention to the practices of the resources poor tribal farmers that makes use of low cost renewable inputs, family and community labour for solving the food crises through their traditional wisdom which need documentation to make the future agriculture a sustainable one. The study on the farmer's traditional wisdom on agriculture was initiated through non-random selection of respondents from Lanjia Saora tribe of Gumma \& Rayagada block of the district. A typical tribal village is situated a little away from the main road and mostly inside the forest. Generally, the houses are constructed on the both side of a wide village road. The cowsheds are constructed on the middle of the road earlier. Now they are having a cowshed in their house in front side or in the end of house row. This system has changed due to reduced number of wild animals and effective forest. Most of the houses have some backyard and they raise a kitchen garden. Gradually, this kitchen garden extends to the field which again merges with the forest. The village has been set up where there was plain land and a stream. This selection of their dwelling place shows their intelligence and foresight. The villagers are used cow-dung like a fertilizer in their own cultivators land. Mostly of the house have same backyard and they raise a kitchen garden. Gradually, this kitchen extends to the field which again merges with the forest. In other hand women are engaged in other agricultural occupations like dairy, farming, horticulture, raising of live-stock, bees and poultry.

Today much of tribal people are loss of livelihood is an indication of displacement, migration and human distress. Scheduled tribe women in search of work in the last few years have been trafficked for work in different parts of the country. The migrant tribal women and girls faced a number of problems immediately after their migration to cities which included difficulty of communication in local language, residential accommodation, employment, education of children, local contacts, adjustment with city life and environment. Women migrants especially from tribal areas to urban areas are highly traumatized.

\section{Reference:-}

1. Census of India (2001) Office of the Registrar General, India, Data Highlights: The Scheduled Tribes Census of India 2001, Orissa.

2. Census of India (2011) final data, Registrar General of India, Data book for PC: $4^{\mathrm{TH}}$ Aug-2014. Census of India 2011, Primary Census Abstract Figure at a Glance India.

3. Chauhan, N. M., \& Thakor, R. (2006). Participation of the tribal farm women in decision making Gujarat J. Ext. Edu., Anand, 16, 55-57.

4. Chayal, K., \& Dhaka, B. L. (2016). Analysis of role performance of women in farm activities. Indian Research Journal of Extension Education, 10(2), 109-112.

5. Haan and Dubey (2003), 'Poverty in Orissa: Divergent Trends? With Some Thoughts on Measurement Issues', Mimeo, Paper presented at the Workshop on 'Monitoring of Poverty in Orissa', 26-27 February, Nabakrushna Choudhury Center for Development Studies, Bhubaneswar.

6. Hans Asha, (2014), "Scheduled Tribe Women of Odisha", Odisha review, November-14, pp. 26-32, 27-40 pdf.

7. Htt://censusindia.goin/Tables_/published/A-Series_links/t_00_005.aspx.11/23/2016

8. Htt://wwwstscodisha.govein/Abouts.asp?GL=abt\&PL=1.11/23/2016

9. Kumar, K. (2006). Dispossessed and displaced: A brief paper on tribal issues in Orissa. Co-Acting Monthly Review of the state and people, $1(1)$.

10. Nigist, S., (2004). Gender Main streamlining world vision.

11. Padhi Kuamani (2017) Agriculture labour in India-A close look, Orissa reviews.

12. Prasad, C., \& Singh, R. P. (1992). Farm women:"A Precious Resources" in Women in Agriculture, Vol. 2. Education, Training and Development edited by RK Punia.

13. Raksha, J. C. (2016). Women: Seeds of Change in Agriculture. Indian Research Journal of Extension Education, 15(3), 72-79.

14. Raksha, J. C. (2016). Women: Seeds of Change in Agriculture. Indian Research Journal of Extension Education, 15(3), 72-79.

15. Source: Data highlights- the scheduled tribes, Orissa, Census of India 2001. 